ҚАЗАҚСТАН РЕСПУБЛИКАСЫ

ҰЛТТЫҚ ҒЫЛЫМ АКАДЕМИЯСЫНЫН

АБАЙ АТЫНДАҒЫ ҚАЗАҚ ҰЛТТЫҚ

ПЕДАГОГИКАЛЫҚ УНИВЕРСИТЕТІНІҢ

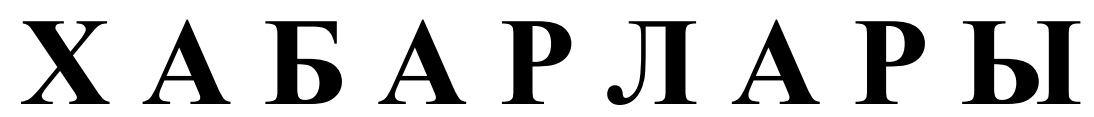

\section{ИЗВЕСТИЯ}

НАЦИОНАЛЬНОЙ АКАДЕМИИ НАУК РЕСПУБЛИКИ КАЗАХСТАН

КАЗАХСКИЙ НАЦИОНАЛЬНЫЙ

ПЕДАГОГИЧЕСКИЙ УНИВЕРСИТЕТ ИМ. АБАЯ

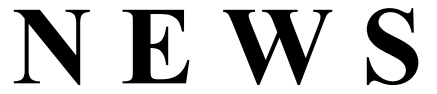

OF THE NATIONAL ACADEMY OF SCIENCES OF THE REPUBLIC OF KAZAKHSTAN

ABAY KAZAKH NATIONAL PEDAGOGICAL UNIVERSITY

ҚОҒАМДЫҚ ЖӘНЕ ГУМАНИТАРЛЫҚ ҒЫЛЫМДАР СЕРИЯСЫ

СЕРИЯ ОБЩЕСТВЕННЫХ И ГУМАНИТАРНЫХ НАУК

$\checkmark$

SERIES OF SOCIAL AND HUMAN SCIENCES

$$
5 \text { (321) }
$$

КЫРКУЙЕК - КАЗАН 2018 ж.

СЕНТЯБРЬ - ОКТЯБРЬ 2018 Г.

SEPTEMBER - OCTOBER 2018

1962 ЖЫЛДЫҢ ҚАНТАР АЙЫНАН ШЫҒА БАСТАҒАН

ИЗДАЕТСЯ С ЯНВАРЯ 1962 ГОДА

PUBLISHED SINCE JANUARY 1962

ЖЫЛЫНА 6 РЕТ ШЫҒАДЫ

ВЫХОДИТ 6 РАЗ В ГОД

PUBLISHED 6 TIMES A YEAR 
Ба с ре дактор

ҚР ҰҒА кұрметті мүшесі

Балықбаев Т.O.

Р е д а ц и я а лқ а сы:

экон. ғ. докторы, проф., ҚР ҰҒА академигі Баймұратов У.Б.; тарих ғ. докторы, проф., ҚР ҰҒА академигі Байпақов К.М.; филос. ғ.докторы, проф., ҚР ҰҒА академигі Есім Г.Е.; фил. ғ. докторы,, проф., ҚР ҰҒА академигі Қирабаев С.С.; эк. ғ. докторы, проф., ҚР ҰҒА академигі Кошанов А.К.; эк.ғ. докторы, проф., ҚР ҰҒА академигі Нәрібаев К.Н. (бас редактордың орынбасары); филос. ғ.докторы, проф., ҚР ҰҒА академигі Нысанбаев А.Н.; заң ғ. докторы, проф., ҚР ҰҒА академигі Сәбікенов С.Н.; заң ғ. докторы, проф., ҚР ҰҒА академигі Сүлейменов М.К.; эк. ғ. докторы, проф., ҚР ҰҒА академигі Сатыбалдин С.С.; тарих ғ. докторы, проф., ҚР ҰҒА академик Әбжанов Х.М.; тарих ғ. докторы, проф., ҚР ҰҒА корр. мүшесі Әбусеитова М.Х.; тарих ғ. докторы, проф., ҚР ҰҒА академик Байтанаев Б.А.; филол. ғ. докторы, проф., ҚР ҰҒА корр. мүшесі Жақып Б.А.; фил. ғ. докторы, проф., академик НАН РК Қалижанов У.К.; филол. ғ. докторы, проф., ҚР ҰҒА академик Қамзабекұлы Д.; тарих ғ. докторы, проф., ҚР ҰҒА академик Қожамжарова Д.П.; тарих ғ. докторы, проф., ҚР ҰҒА академик Койгелдиев М.К.; фил. ғ. докторы, проф., ҚР ҰҒА корр. мүшесі Кұрманбайұлы Ш.; тарих ғ. докторы, проф., ҚР ҰҒА корр. мүшесі Таймағанбетов Ж.К.; социол. ғ. докторы, проф., ҚР ҰҒА корр. мүшесі Шәукенова 3.К.; фил. ғ. докторы, проф., КР ҰҒА корр. мүшесі Дербісәлі А.; саяси. ғ. докторы, проф., Бижанов А.К., тарих ғ. докторы, проф., Кабульдинов 3.Е.; фил. ғ. докторы, проф., ҚР ҰҒА корр мүшесі Қажыбек Е.3.

\section{Р едакция ке н е с i:}

Молдова Республикасының ҰҒА академигі Белостечник Г. (Молдова); Әзірбайжан ҰҒА академигі Велиханлы Н. (Азербайджан); Тәжікстан ҰҒА академигі Назаров Т.Н. (Тәжікстан); Молдова Республикасының ҰҒА академигі Рошка А. (Молдова); Молдова Республикасының ҰҒА академигі Руснак Г. (Молдова); Әзірбайжан ҰҒА корр. мүшесі Мурадов Ш. (Әзірбайжан); Әзірбайжан ҰҒА корр. мүшесі Сафарова 3. (Әзірбайжан); э. ғ. д., проф. Василенко В.Н. (Украина); заң ғ. докт., проф. Устименко В.А. (Украина)

«Қазақстан Республикасы Ұлттық ғылым академиясының Хабарлары. Қоғамдық және гуманитарлық ғылымдар сериясы». ISSN 2224-5294

Меншіктенуші: «Қазақстан Республикасының Ұлттық ғылым академиясы» РҚБ (Алматы қ.)

Қазақстан республикасының Мәдениет пен ақпарат министрлігінің Ақпарат және мұрағат комитетінде 30.04.2010 ж. берілген № 10894-Ж мерзімдік басылым тіркеуіне қойылу туралы куәлік

Мерзімділігі: жылына 6 рет.

Тиражы: 500 дана.

Редакцияның мекенжайы: 050010, Алматы қ., Шевченко көш., 28, 219 бөл., 220, тел.: 272-13-19, 272-13-18, http://nauka-nanrk.kz. social-human.kz

(C) Қазақстан Республикасының Ұлттық ғылым академиясы, 2018

Типографияның мекенжайы: «Аруна» ЖК, Алматы қ., Муратбаева көш., 75. 
Главный редакто $p$

Почетный член НАН РК

T.O. Балыкбаев

Р е дак ци онн а я коллег и я:

докт. экон. Н., проф., академик НАН РК У.Б. Баймуратов; докт. ист. н., проф., академик НАН РК К.М. Байпаков; докт. филос. Н., проф., академик НАН РК Г.Е. Есим; докт. фил. Н., проф., академик НАН РК С.С. Кирабаев; докт. экон. Н., проф., академик НАН РК А.К. Кошанов; докт. экон. Н., проф., академик НАН РК К.Н. Нарибаев (заместитель главного редактора); докт. филос. н., проф., академик НАН РК А.Н. Нысанбаев; докт. юр. Н., проф., академик НАН РК С.Н. Сабикенов; докт. юр. н., проф., академик НАН РК М.К. Сулейменов; докт. экон. Н., проф., академик НАН РК С.С. Сатубалдин; докт. ист. н., проф., академик НАН РК Х.М. Абжанов; докт. ист. н., проф., чл.-корр. НАН РК М.Х. Абусеитова; докт. ист. н., проф., академик НАН РК Б.А. Байтанаев; докт. фил. н., проф., чл.-корр. НАН РК Б.А. Жакып; докт. фиолол. н., проф., академик НАН РК У.К. Калижанов; докт. фил. н., проф., академик НАН РК Д. Камзабекулы; докт. ист. н., проф., академик НАН РК Д.П. Кожамжарова; докт. ист. н., проф., академик НАН РК М.К. Койгельдиев; докт. филол. н., проф., чл.-корр. НАН РК Ш. Курманбайулы; докт. ист. н., проф., чл.корр. НАН РК Ж.К. Таймаганбетов; докт. социол. н., проф., чл.-корр. НАН РК З.К. Шаукенова; д. филол. н., проф., чл.-корр. НАН РК А. Дербисали; доктор политических наук, проф., Бижанов А.К.; доктор ист. наук, проф., Кабульдинов 3.Е.; доктор филол. н., проф., член-корр. НАН РК Қажыбек Е.3.

Р е дак ци онны й с ов е т

академик НАН Республики Молдова Г. Белостечник (Молдова); академик НАН Азербайджанской Республики Н. Велиханлы (Азербайджан); академик НАН Республики Таджикистан Т.Н. Назаров (Таджикистан); академик НАН Республики Молдова А. Рошка (Молдова); академик НАН Республики Молдова Г. Руснак (Молдова); чл.-корр. НАН Азербайджанской Республики Ш. Мурадов (Азербайджан), член-корр. НАН Азербайджанской Республики 3.Сафарова (Азербайджан); д. э. н., проф. В.Н. Василенко (Украина); д.ю.н., проф. В.А. Устименко (Украина)

Известия Национальной академии наук Республики Казахстан. Серия общественных и гуманитарных наук. ISSN 2224-5294

Собственник: РОО «Национальная академия наук Республики Казахстан» (г. Алматы)

Свидетельство о постановке на учет периодического печатного издания в Комитете информации и архивов

Министерства культуры и информации Республики Казахстан № 10894-Ж, выданное 30.04.2010 г.

Периодичность 6 раз в год

Тираж: 500 экземпляров

Адрес редакции: 050010, г. Алматы, ул. Шевченко, 28, ком. 219, 220, тел. 272-13-19, 272-13-18, www:nauka-nanrk.kz / social-human.kz

(C) Национальная академия наук Республики Казахстан, 2018 г.

Адрес типографии: ИП «Аруна», г. Алматы, ул. Муратбаева, 75

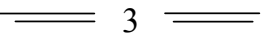


Chief Editor

\section{Honorary member of NAS RK \\ Balykbayev T.O}

Editorial board:

Doctor of economics, prof, academician of NAS RK Baimuratov U.B.; doctor of history, prof, academician of NAS RK Baipakov K.M.; doctor of philosophy, prof, academician of NAS RK Esim G.E.; doctor of philology, prof, academician of NAS RK Kirabayev S.S.; doctor of economics, prof, academician of NAS RK Koshanov A.K.; doctor of economics, prof, academician of NAS RK Naribayev K.N. (deputy editor-in-chief); doctor of philosophy, prof, academician of NAS RK Nyssanbayev A.N.; doctor of law, prof, academician of NAS RK Sabikenov S.N.; doctor of law, prof, academician of NAS RK Suleymenov M.K.; doctor of economy, prof, academician of NAS RK Satybaldin S.S.; doctor of history, prof, academician of NAS RK Abzhanov H.M; doctor of history, prof, corresponding member of NAS RK Abuseitova M.H.; doctor of history, prof, academician of NAS RK Baitanaev B.A.; doctor of philology, prof, corresponding member of NAS RK Zhakyp B.A.; doctor of philology, prof, academician of NAS RK Kalizhanov U.K.; doctor of philology, prof, academician of NAS RK Hamzabekuly D.; doctor of history, prof, academician of NAS RK Kozhamzharova D.P.; doctor of history, prof, academician of NAS RK Koigeldiev M.K.; doctor of philology, prof, corresponding member of NAS RK Kurmanbaiuly Sh.; doctor of history, prof, academician of NAS RK Taimaganbetov J.K.; doctor of sociology, prof, corresponding member of NAS RK Shaukenova Z.K.; doctor of philology, prof, corresponding member of NAS RK Derbisali A.; doctor of political science, prof Bizhanov A.K; doctor of History, prof Kabuldinov Z.E.; doctor of philology, prof, corresponding member of NAS RK Kazhybek E.Z.

\section{Editorial staff:}

Academician NAS Republic of Moldova Belostechnik.G (Moldova); Academician NAS Republic of Azerbaijan Velikhanli N. (Azerbaijan); Academician NAS Republic of Tajikistan Nazarov T.N. (Tajikistan); Academician NAS Republic of Moldova Roshka A. (Moldova) Academician NAS Republic of Moldova Rusnak G. (Moldova); Corresponding member of the NAS Republic of Azerbaijan Muradov Sh. (Azerbaijan); Corresponding member of the NAS Republic of Azerbaijan Safarova Z. (Azerbaijan); Associate professor of Economics Vasilenko V.N. (Ukraine), Associate professor of Law Ustimenko V.A. (Ukraine)

News of the National Academy of Sciences of the Republic of Kazakhstan. Series of Social and Humanities. ISSN 2224-5294

Owner: RPA "National Academy of Sciences of the Republic of Kazakhstan" (Almaty)

The certificate of registration of a periodic printed publication in the Committee of information and archives of the Ministry of culture and information of the Republic of Kazakhstan N 10894-Ж, issued 30.04.2010

Periodicity: 6 times a year

Circulation: 500 copies

Editorial address: 28, Shevchenko str., of. 219, 220, Almaty, 050010, tel. 272-13-19, 272-13-18, www:nauka-nanrk.kz / social-human.kz

(C) National Academy of Sciences of the Republic of Kazakhstan, 2018

Address of printing house: ST "Aruna", 75, Muratbayev str, Almaty 
N E W S

OF THE NATIONAL ACADEMY OF SCIENCES OF THE REPUBLIC OF KAZAKHSTAN

SERIES OF SOCIAL AND HUMAN SCIENCES

ISSN 2224-5294

https://doi.org/10.32014/2018.2224-5294.14

Volume 5, Number 321 (2018), 79 - 84

UDC 657.1(075.8)

\author{
B.A. Markhayeva ${ }^{1}$, D.L.Kozbakhova ${ }^{2}$
}

${ }^{1}$ Almaty Management University, Almaty, Kazakhstan;

${ }^{2}$ South-Kazakhstan Gumanitarian Institute named after M.Saparbaev, Shymkent, Kazakhstan

E-mail: markhaeva@mail.ru, dkozbakhova@mail.ru

\title{
A RESPONSIBILITY CENTER AND TRANSFER PRICING
}

\begin{abstract}
In a divisional organization structure of any kind, if one division (responsibility center) does work that is used by another division, transfer pricing may be required. In general, a divisional structure will lead to decentralization of the decision-making process. In this case the divisional managers may have the freedom to set selling prices, choose suppliers and so on. The creation divisions allows for the operating a system of responsibility accounting. Transfer pricing is used when a company's divisions need to charge other divisions of the same organization for goods and services they provide to them. There are some general rules of transfer pricing. The main purpose of the paper is to consider the methods of transfer pricing in a divisional company. The comparative analysis includes three groups of methods such as market-based, cost-based and negotiation-based approaches. Analysis, classification, generalization and analogy are widely used during the scientific research. The results of the work can be used within a decentralized company's transfer pricing policy. The main conclusion is that the effectiveness of the transfer price depends on the correctness of its calculation. The chosen method depends on the degree of autonomy of the responsibility center in decision-making and the state of the intermediate products market. Nevertheless, it is generally accepted that in conditions of availability of information, the optimal method is the uncontrollable marketbased price method.
\end{abstract}

Key words: responsibility center, division, transfer price, market-based price, cost-based price.

\section{INTRODUCTION}

The company's organizational structure, which consists of several independent divisions, can be considered as a set of different responsibility centers, connected by responsibility branches. From this point of view, in the company's accounting, there was formed such term as a responsibility accounting. Such accounting system ensures the registration, reflection, accumulation, analysis and information provision on costs and revenues of the responsibility centers, and also helps to assess and monitor the activity of a particular manager $[1,2,3,4]$.

Table 1 - Classification of responsibility centers [5-9]

\begin{tabular}{|l|l|l|}
\hline Type of responsibility center & $\begin{array}{l}\text { Manager has control } \\
\text { over... }\end{array}$ & $\begin{array}{l}\text { Principal } \\
\text { performance measure }\end{array}$ \\
\hline Cost center & Controllable costs & $\begin{array}{l}\text { Variance analysis } \\
\text { Efficiency measures }\end{array}$ \\
\hline Revenue center & Revenues only & Revenues \\
\hline Profit center & $\begin{array}{l}\text { Controllable costs } \\
\text { Sales prices (including transfer prices) }\end{array}$ & Profit \\
\hline Contribution center & $\begin{array}{l}\text { As for profit center except that expenditure is reports } \\
\text { as a marginal cost basis }\end{array}$ & Contribution \\
\hline Investment center & $\begin{array}{l}\text { Controllable costs } \\
\text { Sales prices (including transfer prices) } \\
\text { Output volumes } \\
\text { Investment in non-current and working capital }\end{array}$ & $\begin{array}{l}\text { Return On Investment } \\
\text { Residual Income } \\
\text { Other financial ratios }\end{array}$ \\
\hline
\end{tabular}


Thus, the main feature of the responsibility accounting is that it allows you to determine costs and revenues not only within the company, but also in view of their origin and responsibility centers. A responsibility center is a structural unit or a company`s division, with a manager in charge having certain delegated powers. At the same time, the manager's area of responsibility includes only those items of costs and revenues, to which he can influence. Further, the terms a responsibility center and a division are considered as synonyms.

As a rule, in accounting which depends on delegated powers and responsibility area five types of responsibility centers are distinguished such as a cost center, a revenue center, a profit center, a contribution center, an investment center (Table 1).

In other words, the higher the company's degree of decentralization, the more in its structure of profit centers and investment centers, rather than cost centers.

Due to the division into responsibility centers, business transactions between the centers are called transfers, and the prices that result from these operations become transfer prices. On the other hand, transfer prices established within the company are costs for the receiving (selling or consuming) division and revenues for the supplying (transferring or manufacturing) division. This means that internal transfer pricing influences the profitability of each center and based on this it becomes possible to manage the activities of the responsibility centers. Transfer prices allow you to optimize costs and internal financial flows of the company and can significantly enhance its competitiveness. Therefore, the financial manager of the company should pay special attention to the study of transfer pricing methods.

\section{METHODS}

During this research such methods of scientific knowledge as analysis and synthesis, classification, generalization and analogy are widely used.

\section{RESULTS}

From the view of the company's management, transfer prices are conditional-calculated domestic prices, under which the responsibility centers transfer products or services to each other. As mentioned above, a company here refers to a large centralized enterprise that is structurally divided into responsibility centers with a sufficient degree of their autonomy in decision making. No real payments are made. The cost of intra-company supplies is entered in the accounting records and is subsequently reflected in the company's financial statements. The main purpose of transfer pricing is to influence the performance of each responsibility center and to promote the increase in the profit of each center, which should lead to an increase in the company's overall profit.

Factors affecting transfer pricing can be conditionally combined into the following groups:

- presence or absence of a competitive market for an intermediate product. The basic principle of transfer pricing is that the transfer price should be as close as possible to the market price, at which the product can be sold to the external buyers or purchased from the external suppliers. In this case, the responsibility center is autonomous in decision-making, and its activities can be objectively evaluated;

- presence or absence of free capacities in the manufacturing division. If the responsibility center has free production capacities, then for the company as a whole, the purchase of products within the group is more preferable. As a result, the company's profit will increase, as additional production will cover part of the fixed costs that are associated with idle capacities;

- degree of managers qualification: the transfer pricing system requires high qualification of the corporate center's managers. They face the challenge of balancing various conflicting goals in order to achieve an optimal result for the company;

- the bargaining (or negotiation) power of the responsibility centers. Transfer prices between the two centers provoke a conflict between them. The manufacturing division is interested in ensuring that prices are as high as possible, the consuming division, on the contrary, is interested in the lowest possible prices.

There are general rules for transfer pricing. The minimum and the maximum limits of the transfer price can be determined as follows $[5,6,7]$.

The minimum is the sum of the supplying division's marginal cost and opportunity cost of item transferred. The maximum is the lowest market price at which the receiving division could purchase goods or services externally, less any internal cost savings in packaging and delivery. 
The opportunity cost included in determining the lower limit will be one of the following:

- the maximum contribution forgone by the supplying division in transferring internally rather than selling goods externally;

- the contribution forgone by not using the same facilities in the producing division for their next best alternative use.

If there is no external market for the items being transferred, and no alternative uses for the division's facilities, the transfer price equals standard variable cost of production. If there is an external market for the items being transferred and no alternative, more profitable use for the facilities in that division, than the transfer price is the market price.

Transfer pricing methods between responsibility centers can be combined into three large groups such as approaches based on the market price, costs and negotiation [5, 6, 10-13].

If there is a perfect competitive market for the intermediate product, then it is optimal to establish $a$ market-based transfer price for making decisions and evaluating the divisions' activities. Such price will reflect the real economic contribution of the responsibility center to the profit of the whole company. The division's activity is regulated by the market, and the corporate center does not affect its financial results. It may be affirmed that with this pricing method the responsibility center operates autonomously therefore its activity can be evaluated objectively.

The negotiated transfer pricing is acceptable in situations where there are several market prices or selling costs in the internal and external markets are different. This method can be used in the three following conditions:

1) the manufacturing division has the ability to sell products on the side, and the consuming division can purchase products externally in unlimited quantities;

2) the divisions have the same negotiating power;

3) there is a difference between the sales costs while selling products to the external market or within the group.

If at least one of the conditions is not met, there may be a situation, in which managers do not agree on the transfer price. Then the corporate center will have to participate in the establishment of optimal transfer prices which will violate the autonomy of the responsibility centers.

Cost-based approaches to transfer pricing are often used in practice because today the absence of an external market for intermediate products or the fact that the market is imperfect is typical. Depending on completeness of the considered cost price, there are transfer prices based on full or marginal costs distinguished.

Under the transfer prices based on full cost method, full costs (including fixed overheads) incurred by the manufacturing division in the production of the intermediate product are charged to the consuming division. Hence, the obvious disadvantage of this method is that the manufacturing division does not get profit from its work, so it has no motivation for internal supply. Moreover, the price level depends on how the fixed costs are included in the cost price. One of the alternative ways is to establish the planned volume of the delivered products between divisions, before setting the transfer price for the planning period. If the actual volume will differ from the planned one, the manufacturing division will receive profit or incur losses at the end of the period. For example, if the effective capacity is less than planned, then the manufacturing division will show a loss based on the results of the work for the period.

With variable or marginal cost based transfer pricing, marginal costs are usually understood as the short-term variable costs. This method allows, according to the economics, to maximize the company's profit as a whole. However, in this case, the manufacturing division works with a negative financial result which equals to fixed costs. This negatively affects the motivation of the division's employees. Therefore in practice this method is used rarely.

Alternatives to the cost-based methods are a full cost plus and a variable or a marginal cost plus approaches. Common to alternatives is the additional charge to costs. In the first case, the additional charge covers fixed costs and profit, in the second case covers only profit. In practice, determination of the additional charge's amount raises a lot of disputes. The best solution is to establish the additional charge which equals to the industry average profitability provided that the latter can be reasonably calculated. 


\section{DISCUSSION}

The main purpose of the Law of the Republic of Kazakhstan «On Transfer Pricing» is to prevent loss of government revenue in international business operations and transactions [14]. In other words, it regulates the public relations arising from the external transfer pricing in terms of taxation. The basic concepts of these public relations are arm's length principle and market price. Article 12 of this Law specifies five methods for determining the market price such as the method of comparable uncontrolled price, the cost plus method, the resale price method, the profit split method and net margin method. According to the provisions of the Law, if it is not possible to use comparable uncontrolled price method, one of the listed methods is used consistently. The comparable uncontrolled price method is used by comparing the transaction price for products with a market price taking into account the price range for identical products in comparable economic conditions.

The choice of the transfer pricing method also depends on the manager's willingness to take risks. With certainty a firm's profit under full-cost transfer pricing is greater than that under variablecost transfer pricing. Contrary to this benchmark result, variable-cost pricing becomes more profitable than full-cost pricing when the risk-averse manager bears relatively high risk [15]. This finding is correct for the risk-averse production-division manager who faces uncertainty on the outcomes from R\&D investment.

If managers are compensated solely on the basis of their divisional profits, they invest less than the first-best amounts. While compensation contracts based on firm-wide profits alone can induce first-best investments, they impose extra risk on risk-averse managers. In order to stimulate the interdivisional transfers it is recommended using managerial compensation contracts which are linear functions both of divisional profit and firm-wide profit. The terms of trade are determined through negotiations between the two managers. In this case negotiated transfer pricing allows you to share interdivisional risks and characterize its impact on the design of optimal contracts [16].

Comparison of the actual-cost transfer prices with standard-cost transfer prices shows the following results [17]. Firstly, centralized standard-cost transfer pricing dominates the other methods if the central office and the divisions face low cost uncertainty. Secondly, the actual-cost methods dominate the other methods if the central office and the divisions face high cost uncertainty and later, at the trading stage, the buying division receives sufficient cost information. Thirdly, reported standardcost transfer pricing dominates the other methods if the central office and the divisions face high cost uncertainty, and the buyer has insufficient cost information at the trading stage.

In a tax-free world the internal transfer price is set equal to the marginal cost of the supplying division. Extending this solution, it is argued that the optimal internal transfer price should be a weighted average of the pre-tax marginal cost and the most favorable arm's length price [18]. Nevertheless, for internal performance evaluation purposes firms should generally not value internal transactions at the prevailing market price if the supplying division has monopoly power in the external market.

Information technology development also affects transfer pricing. With coarse information technology, negotiated transfer pricing has an informational advantage: managers agree to prices that approximate the firm's cost of internal trade more precisely than cost-based transfer prices. With sufficiently rapid offers, this advantage outweighs opportunity costs of managers' bargaining time, and negotiated transfer pricing generates higher profits than the cost-based method [19]. However, as information technology improves, the informational advantage diminishes. The opportunity costs of managers' bargaining eventually dominate, and cost-based methods generate higher profits.

\section{CONCLUSION}

About 40 percent of all the United States' international trades occurs between related parties, or intrafirm, such as trades between a parent and subsidiary of the same multinational corporation [20]. This information once more draws attention to the relevance of the transfer pricing problem.

If the product (service) of the responsibility center is consumed entirely within the company, the value of the transfer price is accountable and does not affect the financial state of the company as a whole. The problem is only to establish a «fair» price, which will be used for reporting, so that the results of the activity were correctly measured and evaluated. If, however, the responsibility center has the right to 
independently enter the external market, then this circumstance makes it absolutely different to look at the character and content of the transfer price. It is important to note, that, if the responsibility center has the freedom to buy and sell on the external market and there are idle capacities, the transfer price stops to be a purely accounting instrument. It acquires a real economic meaning and expresses the attitude of the divisions not only among themselves, but also with the company as a whole.

The ideal transfer price should encourage the responsibility center manager to accept the best solutions for the company as a whole. As an indicator of optimality, the maximized total marginal profit of the company is widely used. In other words, the company as a whole should win at most and lose at least into the market transactions of the responsibility center. It is this criterion that should be used as the basis for evaluating the manager's activity of the responsibility center.

The application efficiency of the transfer price depends on its calculation accuracy. Nevertheless, in spite of many different methods of pricing in related party transactions, the generally accepted rule is that, in the presence of reliable and sufficient information, the method of comparable uncontrolled (market) price is considered to be the optimal method.

\section{REFERENCES}

[1] Вахрушина М.А. Бухгалтерский управленческий учет: учеб. для студентов вузов, обучающихся по экономическим специальностям / М. А. Вахрушина. - 8-е изд., испр. - М.: Издательство «Омега-Л», 2010. - 570 с.: ил., табл. - (Высшее финансовое образование). ISBN 978(5(370(01917(3 (in Russ.)

[2] Шеремет А.Д. (ред.) Управленческий учёт. Учебное пособие. - М.: ИД ФБК-ПРЕСС, 2000. - 512 с. /Под редакцией А.Д. Шеремета - (Серия «Академия бухгалтера и менеджера»). ISBN 5-89240-029-8 (in Russ.)

[3] Керимов В. Э. Бухгалтерский управленческий учет [Электронный ресурс]: Учебник / В. Э. Керимов. - 8-е изд., изм. и доп. - М.: Издательско-торговая корпорация «Дашков и Ко», 2012. - 484 с. - ISBN 978-5-394-01057-6 (in Russ.)

[4] Кондраков Н.П. Бухгалтерский (финансовый, управленческий) учет. - Учебник. - М., Проспект, 2017. - 512 с. ISBN 978-5-392-21696-3 (in Russ.)

[5] ACCA Approved. Paper F5. Performance Management. Study Text for exams up to June 2015. Seventh edition June 2014. BPP Learning Media Ltd, 2014. ISBN 978147271080 2. www.bpp.com/learningmedia/ (in Eng.)

[6] ACCA Approved - F5 Performance Management - Study Text eBook (September 2017 to June 2018 exams). Becker Professional Education, 2018, ISBN 9781785664342 (in Eng.)

[7] ACCA Kaplan F5 Performance Management (PM) Essential Text 2015. Kaplan Publishing - 2014. - 410 p. - ISBN13: 978-1784150310 (in Eng.)

[8] Друри К. Управленческий и производственный учет. - Учебный комплекс для студентов вузов; пер. с англ. В.Н. Егорова. - 6-е изд. - М.: ЮНИТИ-ДАНА, 2012. - 1423 с. - (Зарубежный учебник). ISBN 978-5-238-01060-1 (in Russ.)

[9] Хорнгрен Ч., Фостер Дж., Датар Ш. Управленческий учет. - 10-е изд. /Пер. с англ. - СПб.: Питер, 2007.- 1008 с.: ил. - (Серия «Бизнес-класс»). ISBN 5-94723-174-3 (in Russ.)

[10] Markhayeva B.A., Karshalova A.D. Management accounting 2. - Study guide. - Almaty, 2017. - 176 p. ISBN $978-$ 601-7470-78-4 (in Eng.)

[11] Мархаева Б.А. Басқару есебі. - Электрондық оқу құралы. - Алматы, Алматы Менеджмент Университеті, 2016. - 252 б. ISBN 978-601-7470-65-4 (in Kazakh)

[12] Назарова В.Л., Жапбарханова М.С., Фурсов Д.А., Фурсов С.Д. Басқару есебі [Техt]: оқулық. - Алматы : Экономика, 2005. - 298 б. - ISBN 9965-685-62-2 (in Kazakh)

[13] Кирова О.А., Назаров Н.Е. Методы трансфертного ценообразования. - Статистика и экономика. 2014. (6):8488. DOI:10.21686/2500-3925-2014-6-84-88 (in Russ.)

[14] Трансферттік баға белгілеу туралы. Қазақстан Республикасының 2008 жылғы 5 шілдедегі N 67-IV Заңы. 2018. http://adilet.zan.kz/kaz/docs/Z080000067 (in Kazakh)

[15] Matsui K. (2012) Cost-based transfer pricing under R\&D risk aversion in an integrated supply chain, International Journal Of Production Economics, vol. 139, issue 1, pp. 69-79. DOI: 10.1016/j.ijpe.2011.10.030 (in Eng.)

[16] Anctil R.M., Dutta S. (1999) Negotiated transfer pricing and divisional vs. firm-wide performance evaluation, Accounting Review, vol. 74, issue 1, pp. 87-104. DOI: 10.2308/accr.1999.74.1.87 (in Eng.)

[17] Pfeiffer T., Schiller U., Wagner J. (2011) Cost-based transfer pricing, Review Of Accounting Studies, vol. 16, issue 2, pp. 219-246. DOI: 10.1007/s11142-011-9140-0 (in Eng.)

[18] Baldenius T., Melumad N.D., Reichelstein S. (2004) Integrating managerial and tax objectives in transfer pricing, Accounting Review, vol. 79, issue 3, pp. 591-615. DOI: 10.2308/accr.2004.79.3.591 (in Eng.)

[19] Dikolli S.S., Vaysman I. (2006) Information technology, organizational design, and transfer pricing, Journal Of Accounting \& Economics, vol. 41, issue 1-2, pp. 201-234. DOI: 10.1016/j.jacceco.2005.06.001 (in Eng.)

[20] Neiman B. (2010) Stickiness, synchronization, and passthrough in intrafirm trade prices, Journal Of Monetary Economics, vol. 57, issue 3, pp. 295-308. DOI: 10.1016/j.jmoneco.2010.02.002 (in Eng.) 
ӘОЖ 657.1(075.8)

\author{
Б.А. Мархаева ${ }^{1}$, Д.Л. Козбахова ${ }^{2}$ \\ ${ }^{1}$ Алматы Менеджмент Университеті, Алматы, Қазақстан; \\ ${ }^{2}$ М.Сапарбаев атындағы Оңтүстік-Қазақстан Гуманитарлық Институты, Шымкент, Қазақстан
}

\title{
ЖАУАПКЕРШІЛІК ОРТАЛЫҚ ЖӘНЕ ТРАНСФЕРТТІК БАҒА БЕЛГІЛЕУ
}

Аннотация. Жұмыстың негізгі мақсаты ол жауапкершілік орталықтардан тұратын компанияның деңгейінде трансферттік баға белгілеудің әдістерін қарастыру болып табылады. Салыстырмалы талдау өзіне үш топ әдістерді қамтыды, олар нарықтық бағаға, шығындарға немесе келіссөздерге негізделген тәсілдемелер. Жұмысты орындау барысында талдау, жіктеу, қорытындылау және ұқсастық сияқты тәсілдер кеңінен қолданылды. Жұмыстың нәтижелерін орталықсыздандырылған компанияның баға белгілеу саясатын жүргізуде қолдануға болады. Негізгі қорытынды трансферттік бағаның тиімділігі оны дұрыс белгілеуге тәуелді екенін көрсетті. Ал таңдалған әдіс жауапкершілік орталықтың дербестік деңгейіне және аралық өнім нарығының жағдайына тығыз байланысты болады. Дегенмен, сенімді және жеткілікті ақпараттың бар болуы кезінде нарықтық бағаға негізделген әдіс оңтайлы болып табылады.

Түйін сөздер: жауапкершілік орталық, бөлімше, трансферттік баға, нарықтық баға, шығынға негізделген баға.

Удк 657.1(075.8)

\section{Б.А.Мархаева ${ }^{1}$, Д.Л. Козбахова ${ }^{2}$}

${ }^{1}$ Алматы Менеджмент Университет, Алматы, Казахстан;

${ }^{2}$ Южно-Казахстанский Гуманитарный Институт им. М.Сапарбаева, Шымкент, Казахстан

\section{ЦЕНТР ОТВЕТСТВЕННОСТИ И ТРАНСФЕРТНОЕ ЦЕНООБРАЗОВАНИЕ}

Аннотация. Основная цель работы заключается в рассмотрении методов трансфертного ценообразования в компании, структурно разделенной на центры ответственности. Сравнительный анализ включает в себя три группы методов, среди них подходы, основанные на рыночной цене, затратах или договорных отношениях. В ходе выполнения работы широко используются такие способы научного познания, как анализ, классификация, обобщение и аналогия. Результаты работы можно использовать при реализации политики трансфертного ценообразования в децентрализованной компании.

Основной вывод заключается в том, что эффективность трансферной цены зависит от правильности ее исчисления. Выбранный метод зависит от степени автономности центров ответственности в принятии решений и состояния рынка промежуточных продуктов. Тем не менее является общепризнанным, что в условиях доступности информации оптимальным является метод неконтролируемой рыночной цены.

Ключевые слова: центр ответственности, подразделение, трансфертная цена, рыночная цена, затратная цена

Information about authors:

Markhayeva B.A. - Almaty Management University, professor-researcher, doctor of economic sciences, markhaeva@mail.ru; https://orcid.org/0000-0002-7354-7125;

Kozbakhova D.L. - South-Kazakhstan Gumanitarian Institute named after M.Saparbaev, master of Economics, dkozbakhova@mail.ru, https://orcid.org/0000-0002-3526-989X 


\section{МАЗМҰНЫ}

Алтыбаева С.М., Савындыков Е.С. Көркем мәтін құрылымындағы мифопоэтикалық модельдеу және мәдени код...... 5 Сембиева Л.М., Мажитов Д.М., Карпиикая М.Е., Хамитова Д.М. Экономиканы жаңғырту жағдайындағы ЕАЭО елдерінің монетарлық жүесінін өзгеруі .....

Құлсариева А.Т., Султанова М.Э., Шайгозова Ж.Н. Фольклор және сәйкестілік: Қазақстанның қазіргі заманғы

мәдениетіндегі тарих, жады және аңыз шығармашылығы ........................................................................................... 19

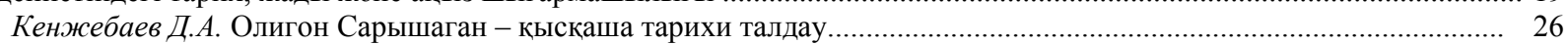

АбдулинаГ.А., БазарбаевА.Г. Ұйымдардағы адам ресурстарын басқарудың заманауи тұжырымдамалары................ 33

Авыбаев А.Н., Адибаева А.К. Геноцид туралы БҰҰ Конвенциясының қатысушы мемлекеттердің қылмыстық

заңнамаларындағы имплементациялық тетіктері: жалпы салыстырмалы талдау............................................................ 39

Ахметжанов Б., Тәжібекова К.Б., Шаметова А.А. Қазақстан көлік өнеркәсіптің дамуын талдау............................. 44

Аюпова 3.К., Құсайынов Д.Ө. Тәуелсіздік жағдайындағы қазақстан республикасының конституциялық-құқықтық

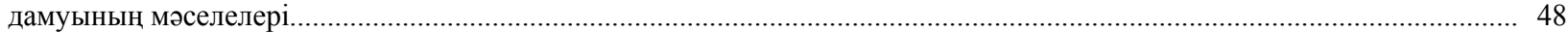

Нурпеисова А.А., Рей И.Ю., Бижанов Д.Т., Тлеужанова Д.А. Инновациялық өндірісді жасаудың процесін

бақылауының негізгі элементтері

Гиздатов Г.Г. Қазақстандық дискурсының құрылымы психолингвистиякалық зерттеу .

Ищанова Р.К. Мемлекеттік шығындарды басқару - мемлекеттің қаржылық тұрақтылығын қамтамасыз ету.............. 64

Мадышева А.М. Бикенова А.С., Елеусиз Л.Т. Білім саласындағы туристік қызметтер............................................. 68

Ескалиева А. Ж., Баймуханова М.Т., Ахмурзина Д.О. Әлеуметтік сала адам капиталының сапасын қолдаудың

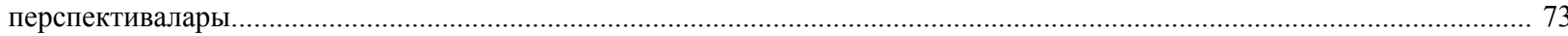

Мархаева Б.А., Козбахова Д.Л. Жауапкершілік орталық және трансферттік баға белгілеу............................................ 79

Сабирова Р.К., Утепкалиева К.М., Кабаков С.Б. Қазақстандағы ауыл шаруашылығы экономикасының

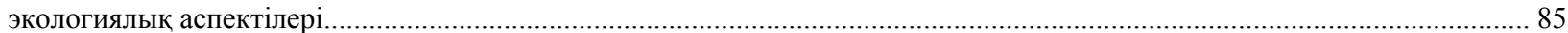

Тлесова Э., Хойч А., Кураш Н. Қазақстан республикасының ғылыми инновациялық потенциясы және оның

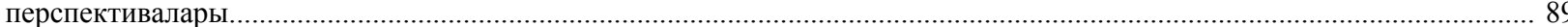

Хамитхан Н. Қазақстандағы банктік қызметтердің сапасын жақсарту жағдайында банкаралык басекелестік............ 95

Шалдарбеков Қ.Б., Муханова Г.С., Нурмухамбетова 3.С. Аймақтарды дамыту бағдарламаларын жүзеге асырудағы жобалық басқаруды қолданудың шетелдік тәжірибесі

КаратаеваА.М., Бердиярова Ж.С. Мемлекеттік қызметшінің әдептік мәдениеті және құқықтық мәдениеті

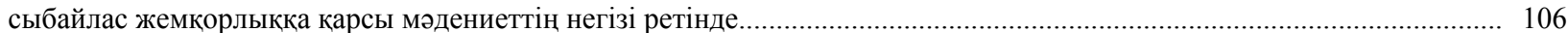

Алдабергенова А.А. Абсурд әдебиетін аударудың лингвомәдени аспектілері ................................................... 113

Стукач В. Ф., Байдалинова А. С., Сандыбаева Б. А. Қазақстанның қаржылық қауіпсіздігі......................................... 119

Баймаханова Д.М., Оспанова Д.А. Конституциялық-құқықтық сана - конституционализмнің маңызды

компоненті ретінде және оның адам құқықтары мәселелерін шешудегі рөлі................................................................. 126

Имангожина 3.А. Сланцевая революция: глобальный тренд на мировом энергетическом рынке............................. 137

Ракаева А.Н., Жуматаева Б.А., Успамбаева М.К., Доскалиева Б.Б. Экологиялық есеп қазақстандағы кәсіпорын экономикасының даму кезеңі ретінде

Нуржанова Г.И. Экономиканың аграрлық секторындағы еңбек әлеуетіне демографиялық фактордың әсері............ 147

Оспанова Д.А., Баймаханова Д.М. Қазақстан Республикасының кибер кеңістігін дамыту жағдайында мемлекеттік қызметтерді цифрландыруда әкімшілік-құқықтық қамтамасыз ету ................................................................................... 152

Pblсnекова М.О., Тлесова Э.Б., Хаитбаева Ф.К. Қазақстандағы тұрғын үй-коммуналдық шаруашылық қызметін

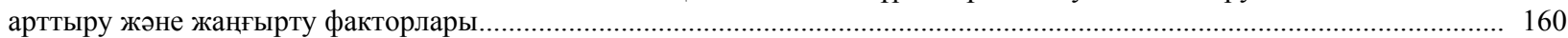

Султанова Г. Т. Аграрлық сектордың экспорттық әлеуетін дамытуға бағытталған үрдістер мен басымдықтар........ 166 


\section{СОДЕРЖАНИЕ}

Алтыбаева С.М., Сагындыков Е.С. Культурный код и мифопоэтическое моделирование в структуре художественного текста.

Сембиева Л.М., Мажитов Д.М., Карпиикая М.Е., Хамитова Д.М. Трансформация монетарной системы стран

ЕАЭС в условиях модернизации экономики.............................................................................................................

Кулсариева А.T., Султанова М.Э., Шайгозова Ж.Н. Фольклор и идентичность: история, память и мифотворчество

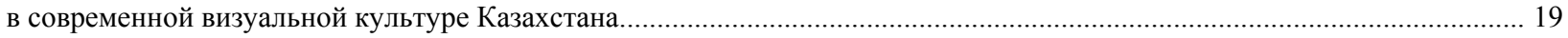

Кенжебаев Д.А. Полигон Сарышаган - краткий исторический анализ................................................................ 26

Абдулина Г.А., БазарбаевА.Г. Современные концепции управления человеческми ресурсами в организациях........... 33

Агыбаев А.Н., Адибаева А.К. Имплементационные механизмы Конвенции ООН о геноциде в уголовных

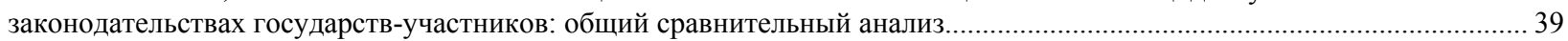

Ахметжанов Б., Тажибекова К.Б., Шаметова А.А. Анализ развития угольной промышленности Казахстана........... 44

Аюпова 3.К., Кусаинов Д.У.Проблемы конституционно-правового развития республики Казахстан в условиях

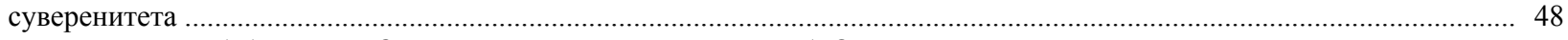

Нурпеисова А.А., Рей И.Ю., Бижанов Д.Т., Тлеужанова Д.А. Основные элементы управления процессом создания

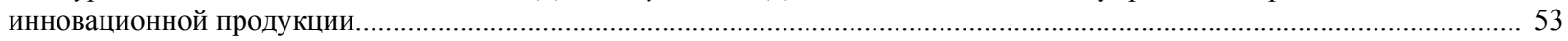

Гиздатов Г.Г. Психолингвистическое исследование концептов казахстанского дискурса...................................... 57

Ищанова Р.К. Управление государственными расходами - как обеспечение финансовой устойчивости государства. 64

Мадымева А.М. Бикенова А.С., Елеусиз Л.Т. Туристские услуги в сфере образования........................................... 68

Ескалиева А. Ж., Баймуханова М.Т., Ахмурзина Д.О. Перспективы усиления качества человеческого капитала

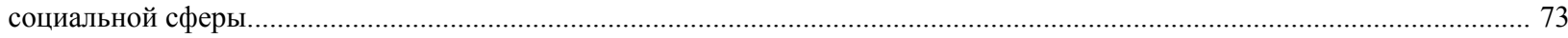

Мархаева Б.А., Козбахова Д.Л. Центр ответственности и трансфертное ценообразование..................................... 79

Сабирова Р.К., Утепкалиева К.М., Кабаков С.Б. Экологические аспекты экономики сельского хозяйства

в Казахстане........................................... 85

Тлесова Э., Хойч А., Кураш Н. Научно-инновационный потенциал республики Казкастан и его перспективы............ 89

Хамитхан Н. Межбанковская конкуренция в условиях повышения качества банковских услуг в Казахстане.............. 95

Шалдарбеков К.Б., Муханова Г.С., Нурмухамбетова 3.С. Зарубежный опыт применения проектного управления

при реализации программ развития регионов

Каратаева А.М., Бердиярова Ж.С. Этическая культура и правовая культура государственных служащих

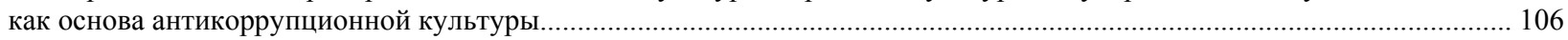

Алдабергенова А.А. Лингвокультурологические аспекты перевода литературы абсурда.......................................... 113

Стукач В. Ф., Байдалинова А. С., Сандыбаева Б. А. Казахстанская финансовая безопасность.................................... 119

Баймаханова Д.М., Оспанова Д.А. Конституционно-правовое сознание как важный компонент конституционализма

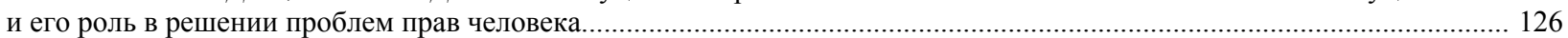

Имангожина 3.A. Сланцевая революция: глобальный тренд на мировом энергетическом рынке............................. 137

Ракаева А.Н., Жуматаева Б.А., Успамбаева М.К., Доскалиева Б.Б. Экологический учет как ступень развития

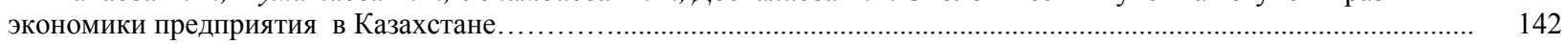

Нуржанова Г.И. Влияние демографического фактора на трудовой потенциал аграрного сектора экономики............ 147

Оспанова Д.А., Баймаханова Д.М. Административно-правовое обеспечение цифровизации государственных услуг

в условиях развития кибер пронстранства республики Казахстан..

Pыспекова М.О., Тлесова Э.Б., Хаитбаева Ф.К. Факторы инновационной модернизации и совершенствования

деятельности жилищно-коммунального хозяйства в Казахстане.

160

Султанова Г. Т. Тенденции и приоритеты развития экспортного потенциала аграрного сектора................................ 166 


\section{CONTENTS}

Altybayeva S.M., Sagyndykov E.S. Cultural code and myth poetic modeling in the structure of the artistic text..................... 5 Sembiyeva L.M., Mazhitov D.M., Karpitskaya M.E., Khamitova D.M. Transformation of the monetary system of the eurasian economic UNION countries in the conditions of modernization of the economy......

Kulsarieva A.T., Sultanova M.E., Shaigozova Zh.N. Folklore and identity: history, memory and myth-making in the modern

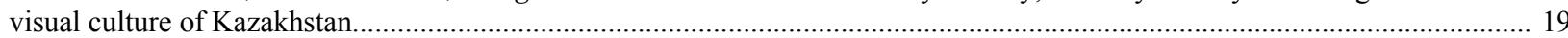

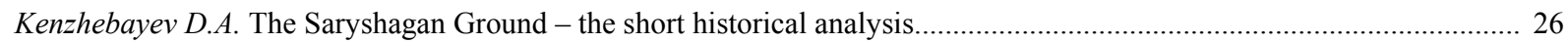

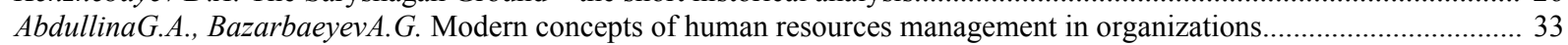

Agybayev A.N., Adibayeva A.K. Implementing mechanisms of the UN Convention on genocide in the criminal legislation

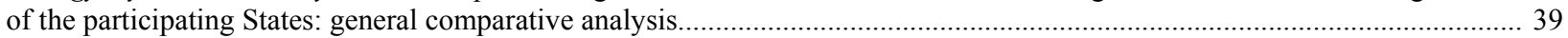

Akhmetzhanov B., Tazhibekova K.B, Shametova A.A. Analysis of development of the coal industry of Kazakhstan.............. 44 Ayupova Z.K., Kussainov D.U. Problems of constitutional and legal development of the republic of kazakhstan in the conditions of sovereignty......

Nurpeisova A.A., Rey I.Yu., Bizhanov D.T., Tleuzhanova D.A. Main elements of managing the process of creating innovation production.

Gizdatov G.G. Psycholinguistic study of the concepts of Kazakhstar

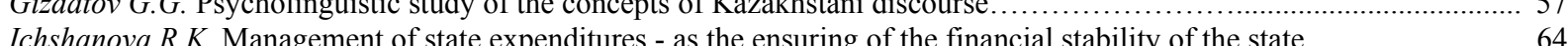

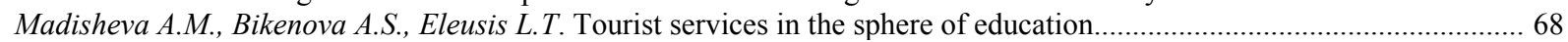

Eskalieva A. Zh., Baymukhanova M.T., Ahmurzina D.O. Perspectives of strengthening the quality of the human capital

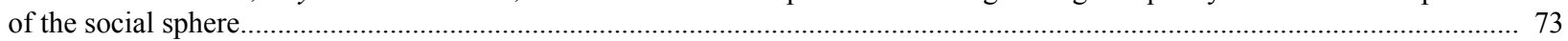

Markhayeva B.A., Kozbakhova D.L. A responsibility center and transfer pricing ................................................. 79

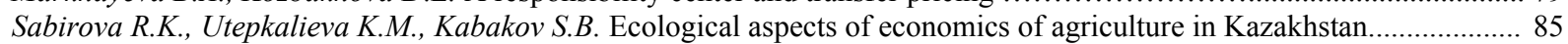

Tlessova E., Khoich A., Kurash N. Scientific innovation potential of the republic of Kazkahstan and its perspectives........ 89

Hamitkhan $N$. Interbank competition in conditions of improving the quality of banking services in Kazakhstan.................. 95

Shaldarbekov K., Mukhanova G., Nurmukhambetova Z. International practices in project management in implementing

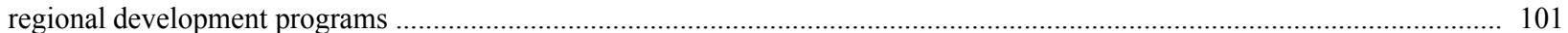

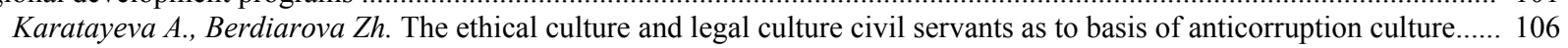

Aldabergenova A.A. Linguocultural aspects of translation of absurd literature.............................................................. 113

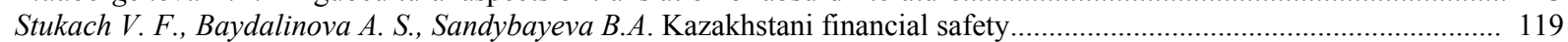

Baimakhanova D.M., Ospanova D.A. Constitutional and legal consciousness as an important component of constitutionalism

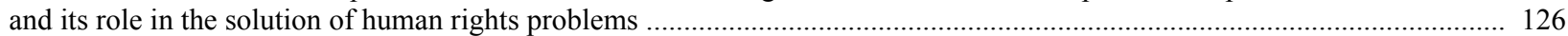

Imangozhina Z.A. Shale gas revolution: global trend in the world energy market..................................................... 137

Rakaeva A.N., Zhumataeva B.A., Uspanbayeva M.K., B.B.Doskalieva. Level of ecological report development in the economic of Kazakhstan's companies.

Nurzhanova G.I. Impact of demographic factors on labor potential of economy's agricultural sector

Ospanova D.A., Baimakhanova D.M. Administrative and legal support of digitalization of public services in the context of the development of cyber space in the republic of Kazakhstan....

Ryspekova M.O., Tlessova E.B., Khaitbayeva F. Factors of innovative modernization and improvement of activity

of housing and communal services in Kazakhstan.

Sultanova G. T. Trends and priorities for the development of export potential of the agrarian sector. 


\title{
PUBLICATION ETHICS AND PUBLICATION MALPRACTICE IN THE JOURNALS OF THE NATIONAL ACADEMY OF SCIENCES OF THE REPUBLIC OF KAZAKHSTAN
}

For information on Ethics in publishing and Ethical guidelines for journal publication see http://www.elsevier.com/publishingethics and http://www.elsevier.com/journal-authors/ethics.

Submission of an article to the National Academy of Sciences of the Republic of Kazakhstan implies that the work described has not been published previously (except in the form of an abstract or as part of a published lecture or academic thesis or as an electronic preprint, see http://www.elsevier.com/postingpolicy), that it is not under consideration for publication elsewhere, that its publication is approved by all authors and tacitly or explicitly by the responsible authorities where the work was carried out, and that, if accepted, it will not be published elsewhere in the same form, in English or in any other language, including electronically without the written consent of the copyrightholder. In particular, translations into English of papers already published in another language are not accepted.

No other forms of scientific misconduct are allowed, such as plagiarism, falsification, fraudulent data, incorrect interpretation of other works, incorrect citations, etc. The National Academy of Sciences of the Republic of Kazakhstan follows the Code of Conduct of the Committee on Publication Ethics (COPE), and follows the COPE Flowcharts for Resolving Cases of Suspected Misconduct (http://publicationethics.org/files/u2/New Code.pdf). To verify originality, your article may be checked by the originality detection service Cross Check http://www.elsevier.com/editors/plagdetect.

The authors are obliged to participate in peer review process and be ready to provide corrections, clarifications, retractions and apologies when needed. All authors of a paper should have significantly contributed to the research.

The reviewers should provide objective judgments and should point out relevant published works which are not yet cited. Reviewed articles should be treated confidentially. The reviewers will be chosen in such a way that there is no conflict of interests with respect to the research, the authors and/or the research funders.

The editors have complete responsibility and authority to reject or accept a paper, and they will only accept a paper when reasonably certain. They will preserve anonymity of reviewers and promote publication of corrections, clarifications, retractions and apologies when needed. The acceptance of a paper automatically implies the copyright transfer to the National Academy of sciences of the Republic of Kazakhstan.

The Editorial Board of the National Academy of sciences of the Republic of Kazakhstan will monitor and safeguard publishing ethics.

Правила оформления статьи для публикации в журнале смотреть на сайте:

$$
\begin{gathered}
\text { www:nauka-nanrk.kz } \\
\text { social-human.kz }
\end{gathered}
$$

\author{
Редакторы М.С. Ахметова, Т.А. Апендиев, Д.С. Аленов \\ Верстка на компьютере А.М. Кульгинбаевой \\ Подписано в печать 10.10.2018 \\ Формат 60x881/8. Бумага офсетная. Печать - ризограф. \\ 11,6 п.л. Тираж 500. Заказ 5.
}

